\title{
Augmented Reality Technology as a Complement on Graphic Design to Face Revolution Industry 4.0 Learning and Competence: The Development and Validity
}

\author{
https://doi.org/10.3991/ijim.v15i05.20905 \\ Asrul Huda ${ }^{(凶)}$, Nelda Azhar, Almasri, Rizky Ema Wulansari, \\ Akrimullah Mubai, Rizki Hardian Sakti, Firdaus \\ Universitas Negeri Padang, Padang, Indonesia \\ asrulhuda@gmail.com \\ Suryo Hartanto \\ Universitas Riau Kepulauan, Batam, Indonesia
}

\begin{abstract}
This study aims at developing the augmented reality application technology, a complementary learning on graphic design to face the skills and learning of the industrial revolution 4.0. This study uses a 4D (four-D) development method for the development of augmented reality application technology and uses a survey method for validity. This AR application will be validated by 12 experts, while the respondents used in filling out the needs analysis questionnaire at the define stage (four-D) are students and lecturers of Informatics Engineering Education, Padang State University. The results of this study indicate that on the analysis of the achievement of the learning process, it can be seen that there are still expectations and advantages in the achievement of the learning process desired by lecturers and students, where the learning process is still in the sufficient category and $80 \%$, students need development of technology as complement reality to be used as learning media in the learning process. The validation test also shows that the augmented reality application technology is included in the valid category with an average value of $\mathrm{V}$ value of 0.933 . So, it cannot be denied that the augmented reality application technology is valid to be used in the learning process.
\end{abstract}

Keywords-Augmented Reality; Revolution Industry 4.0; Graphic Design; Validity

\section{Introduction}

The industrial revolution 4.0 is a new challenge for all countries in the world today. In recent years, a country must be able to prepare competent human resources so that they can compete in the 4.0 industrial revolution. Therefore, the skills they must have are not only academic skills, and technical skills but also higher-order thinking skills, such as problem solving, creative thinking and critical thinking skills [1]. According to Gropelo, Kruse and Tandon (2011) High-order thinking skills are skills that students 
must have in facing the industrial revolution 4.0. Meanwhile, based on the test organized by the OECD (Organization for Economic Cooperation and Development) which is implemented by the Program for International Students (PISA). The results of the PISA test explain that there is a lack of problem-solving skills of students in Indonesia. Based on the 2012 PISA results, Indonesia is ranked 64 out of 65 participating countries, one level above Peru, with a score below the International Standard Value, which is below 500[2].

Therefore, education is one of the vehicles to improve the quality of human resources due to success of the world of education as a determining factor in the achievement of national development goals in the field of education, namely the intellectual life of the nation [3]. The National Education System Law rests on the government's belief in the importance of education in human life, that education is an effort so that humans can develop their potential through a learning process and other methods that are known and recognized by the community.

One of the factors that can help to improve the quality of human resources is through the learning process, and the use of appropriate media is one of the keys. Especially now that we have entered the era of digitalization, the use of computer-based media is one of the right solutions. Learning media using computers as learning media plays an important role in the learning process, where computer-based learning media can develop student skills [4]. One of the computer-based learning media that is effectively used as a learning medium is augmented reality [5]. Augmented reality is the latest evolutionary technology in an era called digitalization era, augmented reality has proven to be effective as a learning tool, because AR accurately simulates the environment of a device with a more real, authentic graphic representation [6][7][8][9][10]. Therefore, the aim of this study is to develop and describe the validity of augmented reality technology as a complement to learning in the face of competence and learning in the industrial revolution 4.0.

\section{Method}

\subsection{Research method and procedures}

This research uses development and survey methods. The development method used is 4Ds [11][12], which consists of define, design, development and disseminate. In this article, the researcher only focuses on the define, design and development stages of augmented reality. The define stage aims at identifying the basic problem so that the development of augmented reality is needed. At the design stage, it consists of making initial designs, such as UML, use case diagrams of augmented reality. Meanwhile, the development stage is the development process of augmented reality. Meanwhile, to reveal the validity of augmented reality that has been developed is to use a survey method. This survey method will provide quantitative results of the validity of the AR application. This AR application will be validated by 12 experts, where the expert assesses the AR application that has been developed through a survey questionnaire given. 


\subsection{Research sample}

The AR application will be validated by 12 experts, where the expert assesses the AR application that has been developed through a survey questionnaire given. These 12 experts were selected based on their scientific fields, those selected were had scientific fields or were experts in the field of informatics and computers, especially augmented reality. While the respondents used in filling out the needs analysis questionnaire at the define stage were students and lecturers of Informatics Engineering Education, Universitas Negeri Padang.

\subsection{Research instruments}

The instruments used in this study were 2 instruments, the first was the needs analysis instrument used to identify the initial problem so that the development of AR applications was needed. In the need analysis instrument, there were 30 questions about students' subjective questions about AR and the learning process. And the second is the validity instrument, there are 30 statement items related to the AR application. In this study, the instrument used was validated using an expert judgment strategy. This validity instrument consists of three categories to be assessed, namely didactic requirements, constructive requirements and technical requirements. In this study, didactic requirements are requirements relating to the process of finding concepts according to the applicable curriculum, showing individual differences so that good media can be used to measure student abilities. Construction requirements are requirements relating to sentence structure, simplicity of use of words and clarity which is essentially appropriate for students to understand. Technical requirements are requirements relating to the use of language, writing, pictures and appearance in making learning media.

\section{$3 \quad$ Results and Discussions}

\subsection{Define stage}

At the define stage, a needs analysis is carried out which aims at examining a phenomenon of the needs of a program to be developed. The questionnaire used in this needs analysis is a collection of information to determine the learning process of Informatics Engineering education students and augmented reality applications. There is still a gap between the current achievement of the learning process and the expected achievement of the learning process (see Table 1).

Table 1. Learning Process Achievement

\begin{tabular}{|c|c|c|}
\hline Mean (Reality) & Mean (Expectation) & Delta Mean \\
\hline 68,21 & 93,32 & 25,11 \\
\hline
\end{tabular}




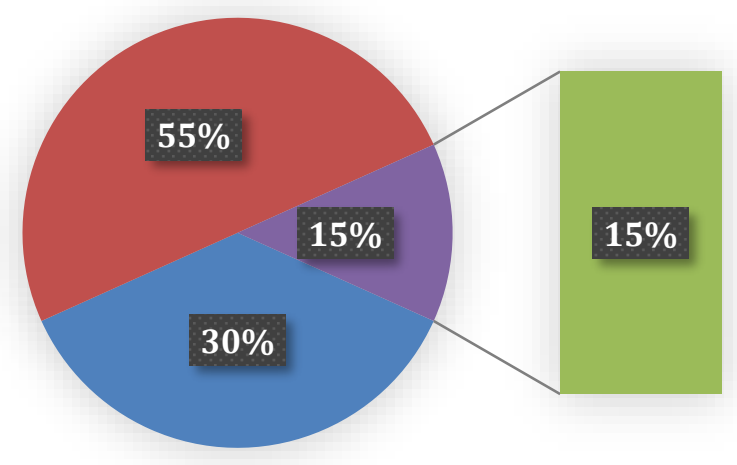

Fig. 1. Presentation of Learning Process Achievement

The data above shows that the level of achievement of the student learning process based on the students and lecturers' opinion is relatively the same, which is still at a sufficient level. The learning process still uses a very simple learning method. It means that lecturers and students are still not optimally utilizing learning methods and media creatively and innovatively.

As a result, students have to repeat the material, and it can spend time that should be used for further discussion of material which can increase student knowledge and students also being inactive in learning due to more activities for listening only. Learning media that must be developed in this case is augmented reality as expected by students (see Fig. 2).

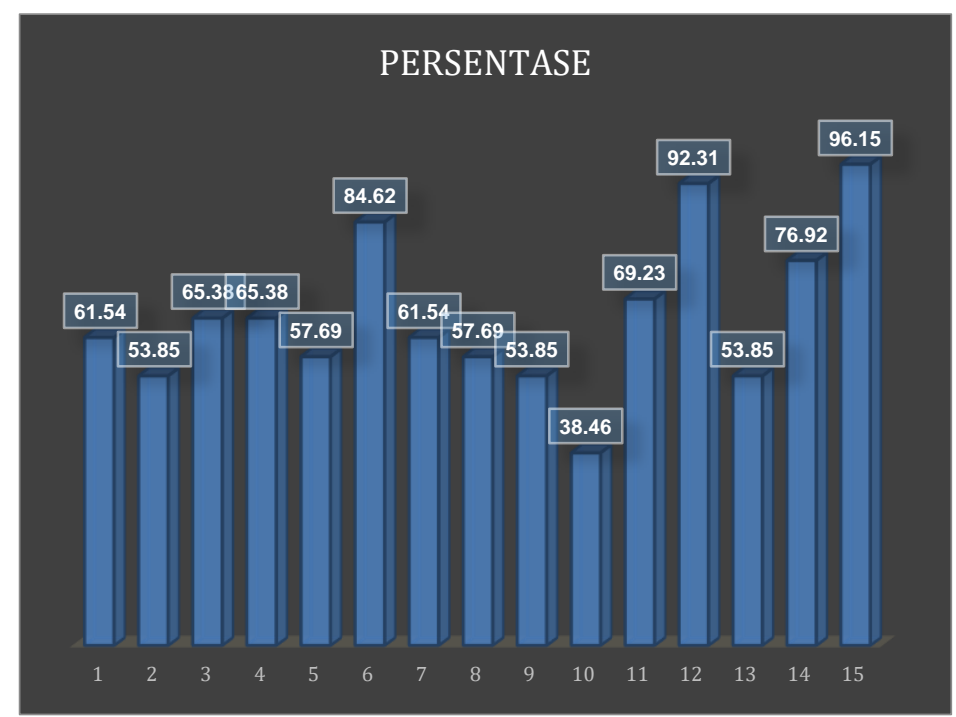

Fig. 2. Presentation of AR Development Need 
Based on Fig. 2, it can be seen that the percentage above $80 \%$ students need the development of augmented reality to be used as a learning medium in the learning process.

\subsection{Design stage}

At this stage, AR media was designed using flowcharts and Unified Modeling Language (UML). In addition, AR media uses a data base to store data about the material being developed. The database used in this expert system-based learning media is MySQL which is then connected to the programming used to build AR media. The database created in this system is a database that contains learning materials, learning videos, questions and all things related to learning.

Flowchart: Flowchart Diagram is a chart to describes or represents an algorithm or procedure for solving problems, here is a flowchart from AR media.

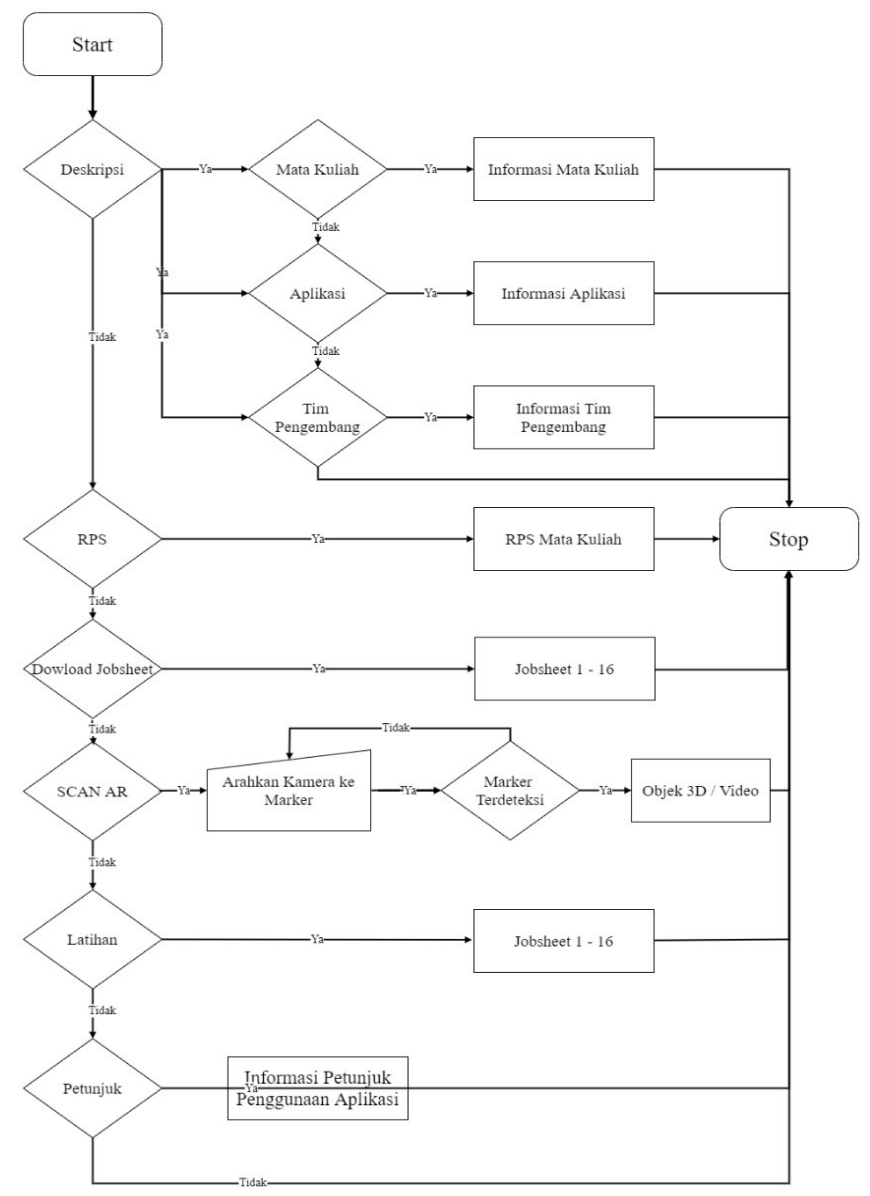

Fig. 3. Flowchart of Augmented Reality 
Fig. 3 describes the flowchart of AR media development, where the flowchart illustrates that there is a material menu, a video menu, a task menu and a discussion forum in AR media. The flowchart describes the AR flow to be developed.

Use case diagram: Fig. 4 below describes the sequence of AR media used by the user. The sequence of using AR media starts from the start form and the user must fill in the login form to create an account for each user, and the user can get an account ID and password. After that, the user can access the AR media. After that, in this AR media the user can access anything related to learning materials, videos and even discussion forums available on the AR media.

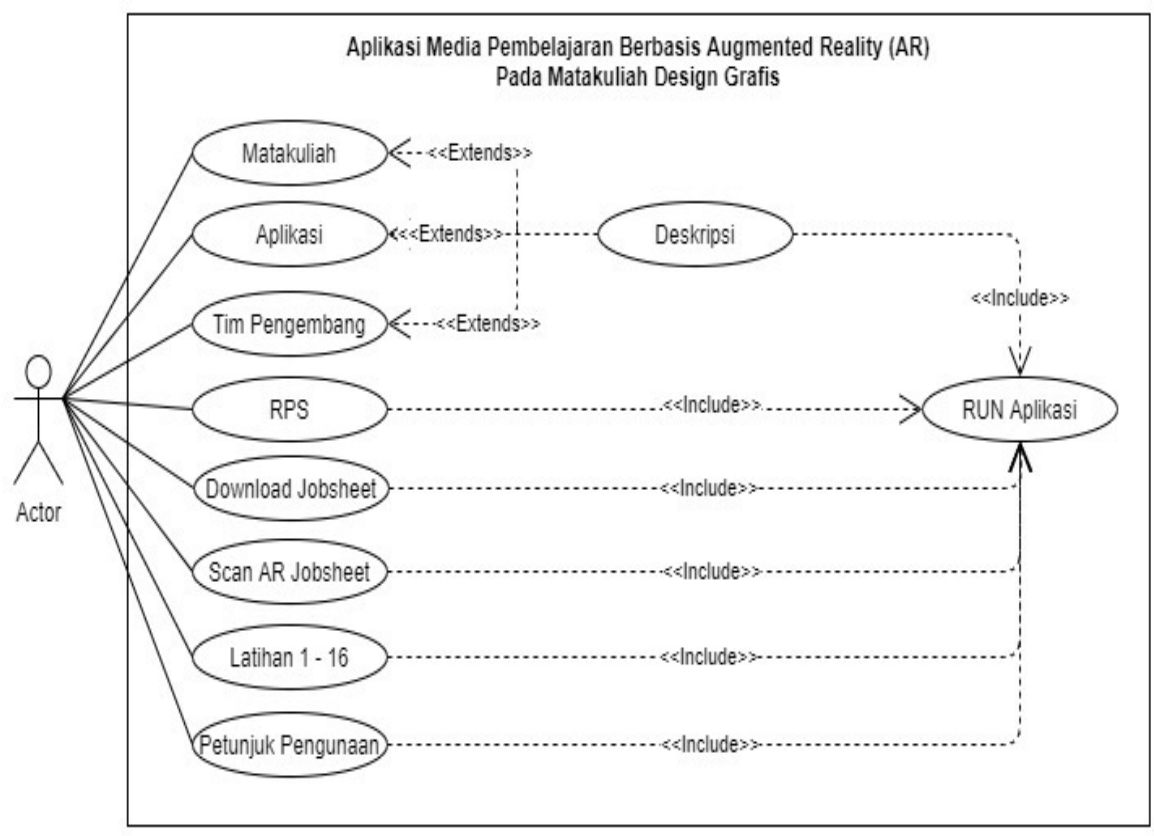

Fig. 4. Use case Diagram of AR Media

Fig. 4 is a Use case Diagram of AR media which explains the flow of AR media use, both in terms of students, admins and non-student users, explaining the sequence of tasks of each user on the AR media.

\subsection{Development stage}

The use of computer facilities, such as augmented reality media is currently very helpful in the learning process because it can help students to understand the material more quickly by displaying videos or real images of a component in the material. AR media can also help students to learn concepts with real experiences, but it can also help 
Paper - Augmented Reality Technology as a Complement on Graphic Design to Face Revolution...

to make the learning process more interesting and attract students to learn. The following is the design result for the AR media application program.

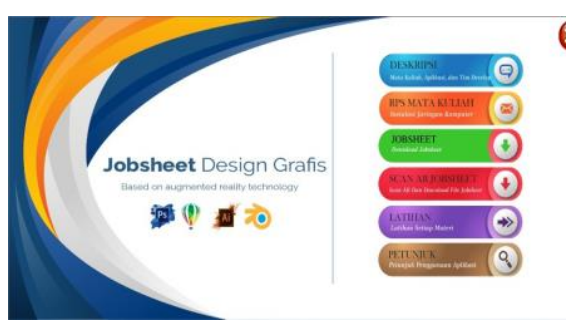

(a) Display of AR Media Start Page

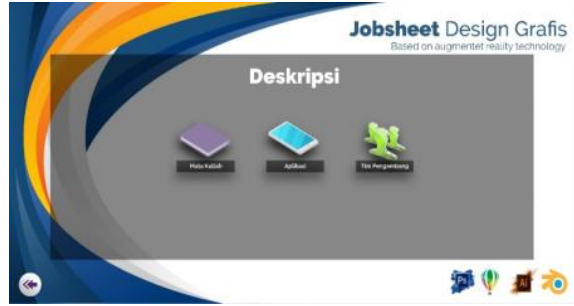

(b) Description Page

Fig. 5.

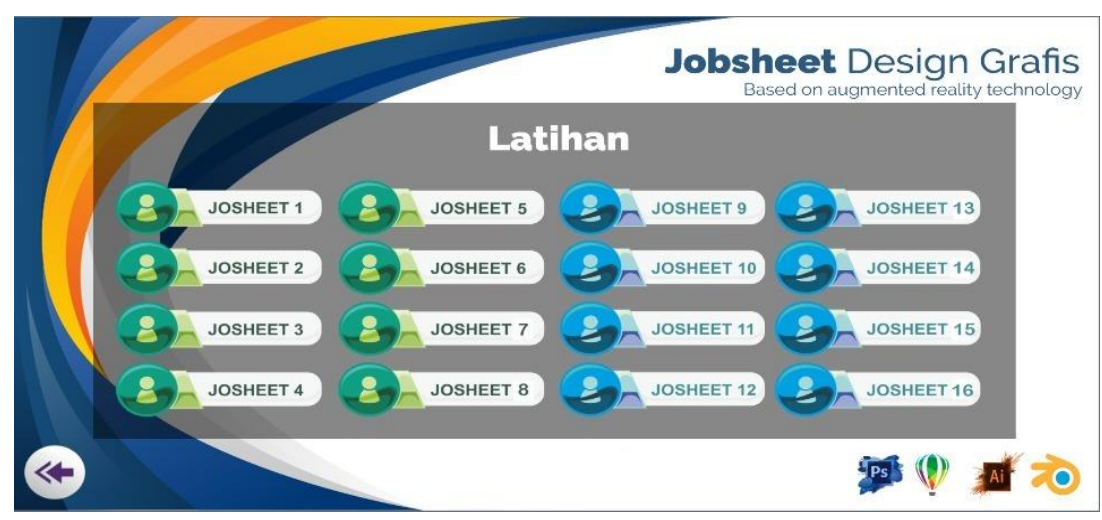

Fig. 6. Display of Assignment Page

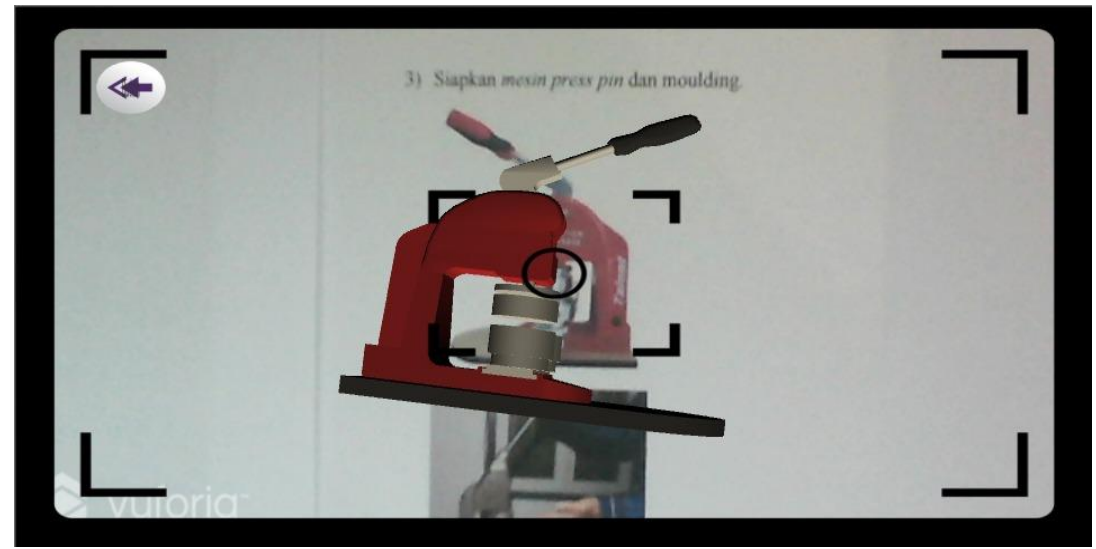

Fig. 7. Display of Augmented Reality Page on Graphic Design Material 


\subsection{Validation test by experts}

Data analysis from the questionnaire used Aiken's V content validity [13][14]. The results of Aiken's calculations range from 0 to 1 and the number 0.6 can be interpreted as having a high enough coefficient and can be stated as a valid category. The results of the expert's assessment of augmented reality were analyzed using the Aiken's V formula which can be seen in Table 2 .

Table 2. The Results of Augmented Reality Validation Analysis

\begin{tabular}{|c|l|c|c|l|}
\hline No & \multicolumn{1}{|c|}{ Assessment Aspects } & $\sum \mathbf{S}$ & V & \multicolumn{1}{|c|}{ Category } \\
\hline 1 & Didactic Requirement & 15 & 1 & Valid \\
\hline 2 & Construction Requirement & 14 & 0,933 & Valid \\
\hline 3 & Technical Requirement & 13 & 0,867 & Valid \\
\hline
\end{tabular}

Based on table 2, the results of the validity test of augmented reality were assessed by 12 experts as validators on the didactic aspects, construction and techniques used with an average value of 0.933 . With the valid value on the didactic requirement is 1 , the construction requirement is 0.933 and the technical requirement is 0.867 . Referring to the validity criteria of Aiken 's V formula model in Azwar (2014), the validated aspects are included in the valid and reliable category $(\mathrm{V}$ value $=0.933$ with the content validation interpretation of the $A R$ is valid because it is in the range between 0 and 1).

Augmented reality is one of the latest technology-based media solutions that can be used by teachers in the learning process either online or not [15]. Augmented reality has characteristics that are appropriate to the era of the industrial revolution. 4.0 currently, where the augmented reality application technology is based on technology that involves students actively, so that augmented reality is one of the computer-based learning media solutions that is relevant to the development of learning in the 4.0 industrial revolution [16].

This study aims at describing the augmented reality application technology that can be used in dealing with learning and competence in the era of the industrial revolution 4.0 and how the development system and the validity of the augmented reality application technology. This research begins with collecting related data before build the augmented reality, namely the define stage. The definition stage is the initial stage of development, this stage is carried out as a basic reference for developing augmented reality application technology, to see how much augmented reality is needed to be developed and used in the learning process [17][18]. At the define stage, an analysis of the achievement of the learning process is carried out and an analysis of the wholeness of augmented reality in the learning process. In the analysis of the learning process achievements, it can be seen that there is still a gap between expectations and reality in the achievement of the learning process desired by lecturers and students, where the learning process achievements are still in the sufficient category. This means that lecturers and students are still not optimally utilizing learning methods and media creatively and innovatively, because learning media is a technique used in presenting material by utilizing sight and hearing effectively to help the learning process for students, so that learning objectives can be achieved by students [19][20][21]. 
The augmented reality application technology is designed using use case diagrams and UML, this is done so that there are no mistakes when building an augmented reality technology application. Users of augmented reality are also given the ability to control existing elements so that users can choose what they want for the next process [22]. The development of this augmented reality application technology is carried out after the UML and use case design has been completed. The use of UML in the development of an application can facilitate development, because UML provides an expressive and ready-to-use visual modelling language for developing and exchanging meaningful models, provides an extension and specialization mechanism for extending core concepts, supports programming language independent specifications and a specific development process, provides a formal basis for the modelling language, integrates best practices in the software industry into widely accepted terminology and notation, provides the ability to represent all concepts relevant to software systems, provides the flexibility required for software concepts new ones [23]. Like the development of Augmented reality carried out by Mubai (2020) which implements Augmented Reality media based on UML [24].

The validation phase of the augmented reality application technology aims at seeing whether the augmented reality application technology is feasible to be implemented in the learning process or not. This augmented reality application technology is validated by 12 experts who have expertise backgrounds in technology, education and even augmented reality in particular. the validity test of augmented reality which was assessed by 12 experts as validators on the didactic aspects, construction and techniques used with an average value of 0.933 , this means that the AR media has been declared valid by the expert. This is because the presentation of material on AR media includes all components which include the consistency of the presentation system, conceptual clarity, suitability of illustrations with material, presentation of text, tables, images, and reference lists, generating motivation to learn at the beginning of the chapter, summary, assessment, feedback. feedback and follow-up [25][26].

\section{Conclusion}

In the analysis of the learning process achievements, it can be seen that there is still a gap between expectations and reality in the learning process achievements desired by lecturers and students, where the learning process achievements are still in the sufficient category and $80 \%$, students need the development of augmented reality to be used as a learning media in learning process. The validation test also shows that the augmented reality application technology is included in the valid category with an average value of $\mathrm{V}$ value of 0.933 . Augmented reality has characteristics that are in accordance with the current era of the industrial revolution 4.0, where augmented reality application technology is based on technology that involves students actively, so that augmented reality is one of the computer-based learning media solutions that are relevant to the development of learning in the 4.0 industrial revolution. The implication of this research is to add references to technology applications for learning that are relevant to 
the current 4.0 industrial revolution. The impact or empirical review of augmented reality application technology has not been studied through this research, so we invite researchers to conduct research in the future on the impact of augmented reality application technology.

\section{$5 \quad$ References}

[1] Gropello, E., Kruse A., \& Tandon, P., (2011). Skills for The Labor Market in Indonesia. Washington: The World bank. https://doi.org/10.1596/978-0-8213-8614-9

[2] Organization for Economic Coperation and Development (OECD). 2013. PISA 2012 Results in Focus. Available in www.oecd.org/pisa

[3] Huda, A., Azhar, N., Almasri \& Fadli. (2019). Design of Learning Media Graphic Design through Android-Technology Based. International Journal of Recent Technology and Engineering (IJRTE). 8 (25), pp. 254-258.

[4] Hawkins, R O. (2016). Using Computer-Assisted Instruction to Build Math Fact Fluency: An Implementation Guide. Intervention In School and Clinic, p. 1-7.

[5] Azuma, R., Baillot, Y., Behringer, R., Feiner, S., Julier, S., \& MacIntyre, B. (2001). Recent advances in augmented reality. IEEE Computer Graphics and Applications, 21, 34-47. https://doi.org/10.1109/38.963459

[6] Chen, C.-M., \& Tsai, Y.-N. (2012). Interactive augmented reality system for enhancing library instruction in elementary schools. Computers \& Education, 59, 638-652. https://doi.org/10.1016/j.compedu.2012.03.001

[7] Cristancho, S. M., Moussa, F., \& Dubrowski, A. (2011). A framework-based approach to designing simulation-augmented surgical education and training programs. The American Journal of Surgery, 202, 344-351. https://doi.org/10.1016/j.amjsurg.2011.02.011

[8] Dunleavy, M., Dede, C., \& Mitchell, R. (2009). Affordances and limitations of immersive participatory augmented reality simulations for teaching and learning. Journal of Science Education and Technology, 18, 7-22. https://doi.org/10.1007/s10956-008-9119-1

[9] Hincapie, M., Caponio, A., Rios, H., \& Mendivil, E. G. (2011). An introduction to augmented reality with applications in aeronautical maintenance. In 13th International Conference on Transparent Optical Networks (ICTON), 2011 (pp. 1-4). Stockholm: IEEE. https://doi.org/10.1109/ICTON.2011.5970856

[10] Jerry, T., \& Aaron, C. (2010). The impact of augmented reality software with inquiry-based learning on students' learning of kinematics graph. In 2nd International Conference on Education Technology and Computer (ICETC), 2010 (pp. V2-1-V2-5). Shanghai: IEEE. https://doi.org/10.1109/ICETC.2010.5529447

[11] Trianto. 2009. Mendesain Model Pembelajaran Inovatif Progresif. Jakarta: Kencana

[12] Alksabeh, M., \& Abuhelaheh, M (2019). Towards a Model of Quality Features for Mobile Social Networks Apps in Learning Environments: An Extended Information System Success Model. iJIM-Vol.13, No.5, 2019, https://doi.org/10.3991/ijim.v13i05

[13] Azwar, Saifuddin. (2014). Reliabilitas dan Validitas. Yogyakarta: Pustaka Pelajar.

[14] N. Ardi and Isnayanti. (2020). "Structural Equation Modelling-Partial Least Square to Determine the Correlation of Factors Affecting Poverty in Indonesian Provinces," IOP Conf. Ser. Mater. Sci. Eng., vol. 846, no. 1 https://doi.org/10.1088/1757-899X/846/1/012054

[15] Saidin, N. F., Halim, N. D. A. \& Yahaya, N. (2015). A Review of Research on Augmented Reality in Education: Advantages and Applications. International Education Studies; Vol. 8, No. 13, p. 1-8. https://doi.org/10.5539/ies.v8n13p1

[16] Chang, G., Morreale, P., \& Medicherla, P. (2011). Applications of Augmented Reality Systems in Education. Proceedings of Society for Information Technology \& Teacher Education International Conference 2010, 1380-1385. 
Paper-Augmented Reality Technology as a Complement on Graphic Design to Face Revolution...

[17] Huda, A., Azhar, N., Almasri, Hartanto. S. \& Anshari, K. (2020). Practicality and Effectiveness Test of Graphic Design Learning Media Based on Android. International Journal of Interactive Mobile Technologies. 14 (4), pp. 192-203. https://doi.org/10.3991/ijim. v14i04.12737

[18] Sutopo, H., Samosir R.s. \& Gatc, J (2019). Mobile Multimedia Evaluation: Development of Stop Drugs Tutorial. iJIM-Vol.13, No.5, 2019. https://doi.org/10.3991/ijim.v13i05.9436

[19] Wulansari, R. E. et al., (2017). Effectiveness of Instructional Media Based Game on Mathematics at Vocational High School. International Journal of Research and Management. Vol. 4, Issue 12 , p. $125-128$

[20] Johnson, Erin Phinney et al., (2010). Variability in Reading Ability Gains as a Function of Computer-Assisted Instruction Method of Presentation. Journal of Computer and Education. Vol. 55, p. 209-217. https://doi.org/10.1016/j.compedu.2010.01.006

[21] Woo, H. L. 2009. Designing Multimedia Learning Environtments Using Animated Pedagogical Agents: Factor and Issues. Journal of Computer Assisted Learning. Vol. 55, p. $203-$ 218. https://doi.org/10.1111/j.1365-2729.2008.00299.x

[22] Huda, A., Rukun, K. \& Hendriyani, Y. (2017). Construction of Graphic Design Interactive CD for Learning Achievement Using Frequency Distribution of Respondents. International Journal of GEOMATE, Vol. 13, Issue 37, pp. 93-97 https://doi.org/10.21660/ 2017.37.Tvet009

[23] Bower, Cathie Howe, Nerida McCredie, Austin Robinson \& David Grover (2014) Augmented Reality in education - cases, places and potentials, Educational Media International, 51:1, 1-15, https://doi.org/10.1080/09523987.2014.889400

[24] Mubai, A., Rukun, K., Giatman, M. \& Edidas, (2020). Needs Analysis in Learning Media Development Based on Augmented Reality (AR) for Computer Network Installation Courses. Jurnal Pendidikan Teknologi Kejuruan. Vol. 3, No. 1, p. 31-35. https://doi.org/ 10.24036/jptk.v3i1.3723

[25] Muslich, Masnur 2010, Textbook writing, Ar-Ruzz Media, Yogyakarta.

[26] Sakti, R. H., Sukardi, Giatman, M., Nazar, E., Waskito, Wakhinuddin, (2020). Flipped Classroom-Computer Based Instruction untuk Pembelajaran Revolusi Industri 4.0: Rancang Bangun dan Analisis Kebutuhan. Edumatic: Jurnal Pendidikan Informatika. Vol. 4, No. 2, p. 63-72. https://doi.org/10.29408/edumatic.v4i1.2074

\section{Authors}

Asrul Huda is affiliated with Universitas Negeri Padang, Padang, Indonesia.

Nelda Azhar is affiliated with Universitas Negeri Padang, Padang, Indonesia.

Almasri is affiliated with Universitas Negeri Padang, Padang, Indonesia.

Rizky Ema Wulansari is affiliated with Universitas Negeri Padang, Padang, Indonesia.

Akrimullah Mubai is affiliated with Universitas Negeri Padang, Padang, Indonesia.

Rizki Hardian Sakti is affiliated with Universitas Negeri Padang, Padang, Indonesia.

Firdaus is affiliated with Universitas Negeri Padang, Padang, Indonesia.

Article submitted 2021-01-07. Resubmitted 2021-02-17. Final acceptance 2021-02-18. Final version published as submitted by the authors. 